\title{
EVALUASI E-LEARNING MENGGUNAKAN ANALYTICAL HIERARCHY PROCESS (AHP)
}

\section{E-learning Evaluation Using Analytical Hierarchy Process (AHP)}

\author{
Cindy Cahyaning Astuti ${ }^{1 *}$, Herlinda Maya Kumala Sari², Nuril Lutvi Azizah ${ }^{3}$ \\ ${ }^{1}$ Jurusan Pendidikan Teknologi Informasi dan Komunikasi, Fakultas Psikologi dan Ilmu Pendidikan, \\ Universitas Muhammadiyah Sidoarjo \\ ${ }^{2}$ Jurusan Manajemen, Fakultas Bisnis Hukum dan Ilmu Sosial, Universitas Muhammadiyah Sidoarjo \\ ${ }^{3}$ Jurusan Elektro, Fakultas Sains dan Teknologi, Universitas Muhammadiyah Sidoarjo \\ Jalan Mojopahit 666 B Sidoarjo, Jawa Timur, Indonesia \\ e-mail: ${ }^{*}$ cindy.cahyaning@umsida.ac.id ; ${ }^{2}$ herlindamayakumala@umsida.ac.id ; \\ 3nurillutviazizah@umsida.ac.id
}

Corresponding author*

\begin{abstract}
Abstrak
E-learning merupakan media pembelajaran yang mulai digunakan di berbagai perguruan tinggi, meskipun tidak digunakan 100\% karena sebagian masih menggunakan tatap muka. Proses pembelajaran e-learning yang masih baru perlu dievaluasi agar menjadi lebih baik lagi. Tujuan penelitian ini adalah mengevaluasi pembelajaran -learning untuk mengetahui seberapa besar metode tersebut dapat diterima oleh mahasiswa. Alat yang kami gunakan untuk mengevaluasi adalah Analytical Hierarchy Process (AHP). Hasilnya menunjukkan bahwa mahasiswa masih lebih suka metode tatap muka daripada e-learning karena dengan tatap muka materi lebih mudah diserap dan interaksi dengan dosen lebih terjalin jika dibandingkan menggunakan e-learning. Namun, e-learning mempunyai kelebihan yaitu waktu yang lebih fleksibel dibandingkan tatap muka, serta pengumpulan tugas dirasa lebih mudah dengan e-learning.
\end{abstract}

Kata Kunci : e-learning, analytical hierarchy process, tatap muka, pembelajaran

\begin{abstract}
E-learning is a learning media that is being used in various universities, although it is not used 100\% because some still use face to face. Because it is still new, e-learning needs to be evaluated to make it even better. The purpose of this study is to evaluate e-learning to find out how much the method can be accepted by students. The tool we use to evaluate is the Analytical Hierarchy Process (AHP). The results show that students still prefer face-to-face methods rather than e-learning because face-to-face material is more easily absorbed and interactions with lecturers are more interwoven than using e-learning. But e-learning has the advantage of being more flexible than face-to-face, and gathering tasks are easier with e-learning.
\end{abstract}

Keywords: e-learning, analytical hierarchy process, face to face, learning 


\section{PENDAHULUAN}

Saat ini perkembangan teknologi informasi telah sangat pesat, khususnya teknologi internet. Satu diantara sekian banyak pemanfaatan teknologi internet yang mendukung proses pembelajaran adalah $e$ learning. Dengan memanfaatkan e-learning, guru atau dosen tidak berinteraksi tatap muka secara langsung. Mereka dapat menaruh bahan ajar (berupa tulisan, video, dll), memberi tugas, memberi kuis, menjalin komunikasi dengan siswa melalui internet. Keunggulan menggunakan sistem ini adalah proses belajar mengajar dapat dilakukan kapanpun dan dimanapun. Pengembangan metode pembelajaran dari metode tatap muka ke e-learning dilakukan demi peningkatan mutu pendidikan melalui penggunaan teknologi internet. Saat ini mulai banyak sekolah-sekolah dan perguruan tinggi yang mencoba metode pembelajaran e-learning. E-learning belum diterapkan secara resmi di Universitas Muhammadiyah Sidoarjo, namun telah banyak dosen mulai menggunakan e-learning untuk proses pembelajaran. Sejauh ini, metode e-learning tersebut hanya digunakan saja tanpa adanya proses evaluasi. Oleh karena itu, penelitian ini dilakukan guna mengevaluasi proses pembelajaran yang menggunakan e-learning. Aplikasi $e$-learning yang digunakan pada penelitian ini adalah edmodo. Pertimbangan meggunakan edmodo karena aplikasi ini dapat diakses menggunakan Browser, Android maupun IOs. Proses evaluasi pembelajaran tersebut dilakukan dengan pendekatan Analytical Hierarchy Process (AHP).

Terdapat beberapa penelitian terkait evaluasi pembelajaran e-learning yaitu penelitian yang dilakukan oleh Yamasari (2008) yang berjudul "Fasilitas Evaluasi yang Menggabungkan Pengukuran, Bimbingan dan Penilaian dalam Sistem E-learning". Penelitian ini mengevaluasi e-learning dengan metode yang hampir mirip dengan ujian online yang menggunakan kuesioner sebagai alat bantu analisis. Kuesioner tersebut berisikan pertanyakan yang dijawab dalam bentuk pernyataan benar salah serta pertanyaan yang dijawab dalam bentuk uraian [1]. Evaluasi e-learning untuk pembelajaran program KB dilakukan oleh Suparto (2012). Evaluasi e-learning tersebut menggunakan standar kesesuaian yaitu pengukuran dalam evaluasi dilakukan melalui cara membandingkan kenyataan yang ada dengan kriteria tentang bagaimana seharusnya pelaksanaan program itu terjadi. Pendekatan yang digunakan adalah FGD (Focus Group Discussion) [2]. Pada penelitian Sutedjo (2013) fokus penelitian mentiberatkan pada evaluasi sistem e-learning yang dilakukan dengan cara menanyakan ke mahasiswa terkait kritik dan saran pelaksanaan pembelajaran berbasis e-learning [3]. Evaluasi $e$-learning yang dilakukan oleh Hanum (2013) menggunakan model discrepancy atau dikenal juga evaluasi kesenjangan program. Pada penelitian tersebut terlihat kesenjangan program yang terjadi antara yang diharapkan dengan pelaksanaan program atau kenyataan. Serupa dengan penelitian yang dilakukan Pudjo Suparto, namun enelitian Hanum menggunakan ukuran-ukuran kuantitatif yang menggolongkan apakah hasilnya efektif atau tidak. Penilaian dilakukan berdasarkan komponen standar mutu e-learning yaitu perencanaan, perancangan dan pembuatan materi, penyampaian, interaksi dan evaluasi [4]. Usaheni dan Fahmi (2013) melakukan evaluasi tingkat kematangan e-learning menggunakan eMM (e-learning maturity model). Dalam eMM, tingkat kematangan digambarkan sebagai 5 dimensi kapabilitas untuk memastikan sejauh mana proses pengembangan serta pemanfaatan pembelajaran melalui $e$-learning. [5] Dimensi tersebut adalah delivery, planning, definition, management, optimisation [5]. Pemanfaatan media e-learning pada penelitian Rolisca dan Achadiyah (2014) fokus pada penggunaan e-learning pada kegiatan ujian. Penelitian ini membandingkan efektifitas ujian online dengan ujian konvensional. Hasil penelitian menunjukkan siswa lebih termotivasi menggunakan ujian online daripada menggunakan ujian konvensional. Kelebihan penggunaan e-learning untuk ujian yaitu lebih murah, dapat dilakukan sewaktu-waktu, siswa lebih semangat dan tidak takut saat menggunakan e-learning, tidak membosankan, nilai ujian dapat langsung diketahui, rekap ujian semakin dipermudah. Sedangkan kekurangan penggunaan e-learning untuk ujian yaitu tidak dapat dilakukan tanpa jaringan internet, media hanya dapat diakses melalui komputer, keamanan ujian menggunakan e-learning masih perlu pengawasan guru agar tidak terdapat kecurangan [6]. Evaluasi $e$ learning pada penelitian Felix (2014) menggunakan pendekatan kualitatif . Hasil evaluasi menunjukan pengolahan e-learning masih belum maksimal karena tidak adanya tindakan evaluasi yang pasti. Masalah yang timbul saat diterapkan e-learning secara umum terkait dengan waktu dan keinginan dalam menggunakan e-learning serta kesadaran diri dari mahasiswa yang masih kurang untuk memulai menggunakan metode e-learning sebagai metode pembelajaran modern [7]. Penelitian tentang pengembangan media pembelajaran berbasis e-learning juga dilakukan oleh Ahadiah (2016) yang menunjukkan bahwa penggunakan e-learning pada media pembelajaran dapat meningkatkan keaktifan siswa karena proses belajar mengajar berproses pada siswa[8]. Model CSE-ECLA digunakan untuk evaluasi $e$ learning pada penelitian Divayana (2017). Evaluasi dilakukan dari mulai dari komponen system assessment sampai dengan program certification. Terdapat standar penentu kualitas yang diukur menggunakan persentase. Hasil persentase evaluasi dibandingkan dengan standar kualiatas sehingga dapat diketahui apakah 
penggunaan sistem e-learning sudah melebihi standar kualitasnya atau belum. Dilihat dari hasil, e-learning dapat dikatakan berhasil karena hasil evaluasi menunjukan nilai di atas tandar yang ditentukan baik itu pada komponen system assessment sampai dengan program certification [9].

Penelitian ini mencoba pendekatan yang berbeda dari penelitian sebelumnya yaitu dengan menggunakan metode AHP. Metode AHP adalah sebuah metode terstruktur untuk mengatur dan menganalisis keputusan yang kompleks berdasarkan pendekatan matematika dan psikologi. Dalam kasus ini, peneliti ingin mengetahui mana yang lebih efektif antara proses pembelajaran menggunakan metode tatap muka atau metode e-learning. Perspektif yang digunakan sebagai pengambilan keputusan menggunakan AHP pada penelitian ini dibatasi dari segi mahasiswa. Berdasarkan penelitian ini dapat diketahui proses pembelajaran mahasiswa lebih cocok menggunakan metode tatap muka atau metode e-learning serta hal-hal apa saja yang menjadi pertimbangan keputusan tersebut.

Penelitian mengenai e-learning ini dirasakan sangat penting dan sangat dibutuhkan karena suatu saat mau tidak mau pembelajaran akan mengarah pada penggunaan e-learning. Dengan adanya penelitian ini maka diharapkan bisa memberikan gambaran awal mengenai kesiapan mahasiswa dalam menggunakan $e$ learning serta dapat diketahui pula hal-hal apa yang perlu disiapkan dalam menghadapi era pembelajaran modern menggunakan e-learning di masa yang akan datang.

\section{METODE PENELITIAN}

Metode pada penelitian ini secara ringkas disajikan pada bagan alir sebagai berikut:

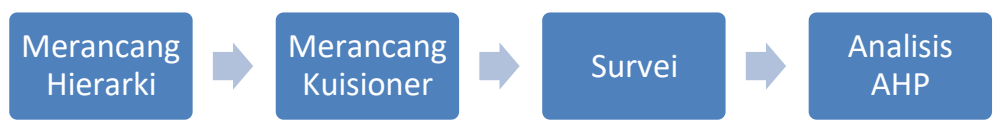

Gambar 1. Bagan Alir Penelitian

Berdasarkan Gambar 1, proses perancangan hierarki merupakan tahap awal yang selalu dilakukan bila penelitian menggunakan alat analisis AHP. Tahap berikutnya setelah rancangan hierarki, dilanjutkan merancangan kuesioner. Survei dilakukan kepada mahasiswa di delapan kelas yang berbeda di mana di kelas tersebut memadukan pembelajaran e-learning dan tatap muka. Kemudian dilakukan analisis AHP untuk mengetahui metode pembelajaran mana yang menjadi prioritas utama mahasiswa saat ini.

\subsection{Rancangan Hierarki}

Rancangan hierarki pemilihan metode pembelajaran yang dibangun menggunakan 4 kriteria yaitu fleksibilitas waktu kuliah, kemudahan memahami materi, kemudahan pengumpulan tugas dan kemudahan interaksi dengan pengajar seperti yang dapat dilihat pada Gambar 2. Terdapat dua alternatif yaitu tatap muka dan e-learning.

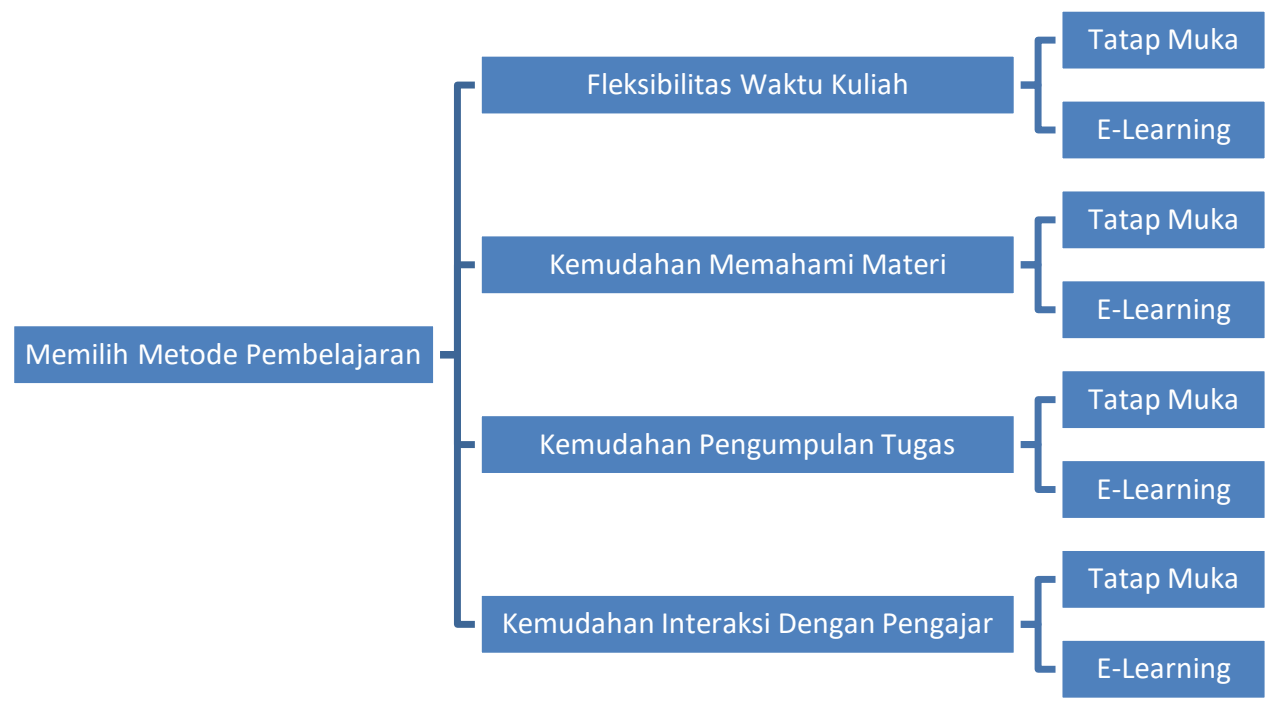

Gambar 2. Rancangan Hierark 


\subsection{Rancangan Kuesioner}

Pada kuesioner terdapat beberapa bagian yang ditanyakan. Bagian pertama mengenai identitas (nama, jenis kelamin, jurusan/fakultas. Bagian kedua menanyakan mengenai lebih suka metode $e$-learning atau tatap muka. Bagian ketiga berupa skala likert untuk menilai metode pembelajaran yang disuka berdasarkan 4 kriteria pada Gambar 2. Bagian ke empat adalah menanyakan prioritas dari masing-masing kriteria dan bagian terakhir merupakan saran.

\subsection{Sampling}

Sampling yang digunakan adalah cluster random sampling di mana sampel diambil dari masingmasing cluster ( kelas) sesuai dengan proporsi. Populasi pada penelitian ini adalah sebesar 237 mahasiswa dengan rincian dapat dilihat pada Tabel 1.

Tabel 1. Populasi Penelitian

\begin{tabular}{|lc|}
\hline \multicolumn{1}{|c}{ KELAS } & Mahasiswa \\
\hline STATISTIKA DASAR PGSD 3-A1 & 42 \\
STATISTIKA DASAR PGSD 3-A2 & 36 \\
STATISTIKA DASAR PGSD 3-B1 & 25 \\
STATISTIKA DASAR PGSD 3-B2 & 24 \\
STATISTIKA P.IPA 5-A1 & 18 \\
STATISTIKA P.IPA 5-B1 & 8 \\
STATISTICS PBI 5-A1 & 24 \\
STATISTICS PBI 5-A2 & 22 \\
STATISTICS PBI 5-B1 & 15 \\
KALKULUS PTI 1-A1 & 23 \\
Total & 237 \\
\hline
\end{tabular}

Rumus Slovin digunakan untuk menghitung banyak sampel dengan tingkat kesalahan yang ditoleransi sebesar $10 \%[10]$.

$$
n=\frac{N}{1+N e^{2}}=\frac{237}{1+237 \times 0.1^{2}}=70.33 \approx 71
$$

Banyak sampel yang diperoleh menggunakan rumus Slovin adalah 70.33, namun kerena jumlah orang tidak mungkin desimal maka dilakukan pembulatan ke atas (Round $U p$ ) sehingga didapatkan sampel sebanyak 71 orang. Hasil tersebut dibagi sesuai dengan proporsi, sehingga didapatkan sampel masing-masing kelas sebagai berikut:

$$
\begin{aligned}
& n_{\text {STATISTIKA DASAR PGSD 3-A1 }}=71 \times \frac{42}{237}=12.58 \approx 13 \\
& n_{\text {STATISTIKA DASAR PGSD } 3-A 2}=71 \times \frac{36}{237}=10.78 \approx 11 \\
& n_{\text {STATISTIKA DASAR PGSD } 3-B 1}=71 \times \frac{25}{237}=7.49 \approx 8 \\
& n_{\text {STATISTIKA DASAR PGSD 3-B2 }}=71 \times \frac{24}{237}=7.19 \approx 8 \\
& n_{\text {STATISTIKA P.IPA } 5-A 1}=71 \times \frac{18}{237}=5.39 \approx 6 \\
& n_{\text {STATISTIKA P.IPA } 5-B 1}=71 \times \frac{8}{237}=2.40 \approx 3 \\
& n_{\text {STATISTICS PBI 5-A1 }}=71 \times \frac{24}{237}=7.19 \approx 8 \\
& n_{\text {STATISTICS PBI 5-A2 }}=71 \times \frac{22}{237}=6.59 \approx 7 \\
& n_{\text {STATISTICS PBI 5-B1 }}=71 \times \frac{15}{237}=4.49 \approx 5 \\
& n_{\text {SKALKULUS PTI } 1-A 1}=71 \times \frac{23}{237}=6.89 \approx 7
\end{aligned}
$$




\subsection{Analisis AHP}

Konsep AHP yang dipakai tidak menggunakan kuesioner tipe perbandingan dengan skala 9 seperti yang ada pada expert choice [11] namun, merujuk pada AHP yang telah dimodifikasi menggunakan skala likert yang dipelajari dari penelitian Herlina Ekawati [12]. Skala likert sendiri merupakan skala yang menunjukkan derajat kesetujuan terhadap suatu pernyataan. Skala likert berukuran ganjil misalkan $1 \mathrm{~s} / \mathrm{d} 3,1$ s/d 5, $1 \mathrm{~s} / \mathrm{d} 7$. Skala likert digunakan dengan pertimbangan agar kuesionernya lebih ringkas sehingga, responden tidak malas mengisi walaupun dalam tahap analisisnya perlu mengkonversi skala likert menjadi skala perbandingan dengan memanfaatkan rata-rata geometri [13].

Berikut ini analisis AHP yang kami lakukan[14]:

1. Menghitung nilai Rata-Rata Geometrik

$$
R G=\sqrt[\sum_{s=1}^{k} m_{s}]{\prod_{s=1}^{k} s^{m_{s}}}
$$

dengan

$s$ : skor

$k:$ skor tertinggi

$m_{\mathrm{s}}$ : banyak skor $\mathrm{s}$

Rata-rata geometrik dihitung dari masing-masing kriteria dan alternatif per kriteria.

2. Menghitung nilai Selisih Terbesar

$$
S T=R G_{\max }-R G_{\min }
$$

$R G_{\text {max }}=$ rata-rata geometrik yang paling besar antar kriteria/alternatif

$R G_{\min }=$ rata-rata geometrik yang paling kecil antar kriteria/alternatif

3. Menghitung Matriks Banding Berpasangan

Matriks Banding Berpasangan berukuran $\mathrm{f} x \mathrm{f}$ di mana $\mathrm{f}$ adalah banyaknya kriteria/alternatif, dan berisi:

$$
\begin{aligned}
& a_{i i}=1 \\
& \text { Jika } R G_{i}>R G_{j}, \text { maka } \\
& a_{i j}=\frac{\left(R G_{i}-R G_{j}\right)}{S T} \times 8+1 \\
& \text { dan } \\
& a_{j i}=\frac{1}{a_{i j}}
\end{aligned}
$$

Di mana $i$ dan $j=1,2, \ldots, f$ dan $f$ adalah banyaknya kriteria/alternatif

4. Menghitung Matriks Normalitas

Matriks normalitas berukuran $\mathrm{f} x \mathrm{f}$ juga, sambung:

$$
\begin{aligned}
& b_{i j}=\frac{a_{i j}}{a_{. j}} \\
& \text { dan } \\
& a_{. j}=\sum_{i=1}^{f} a_{i j}
\end{aligned}
$$

Di mana $i$ dan $j=1,2, \ldots, f$ dan $f$ adalah banyaknya kriteria/alternatif

5. Menghitung Vektor Eigen

Vektor Eigen didapatkan dengan menghitung rata-rata dari masing-masing baris pada Matriks Normalitas.

$$
w_{i}=\frac{\sum_{j=1}^{f} b_{i j}}{f}
$$


6. Menghitung Lamda Maksimal

$$
\lambda_{\text {maks }}=\frac{\sum_{i=1}^{f} \Sigma_{j=1}^{f} a_{i j} w_{w_{i}}}{f}
$$

Di mana $i$ dan $j=1,2, \ldots, f$ dan $f$ adalah banyaknya kriteria/alternatif

7. $\mathrm{CI}$

Consistency Index (CI) dihitung dengan rumus:

$$
C I=\frac{\lambda_{m a k s}-f}{f-1}
$$

8. $\mathrm{CR}$

Consistency Ratio (CR) digunakan untuk mengetahui apakah matriks perbandingan dinyatakan konsisten atau tidak. Pada $\mathrm{f}=3$ dikatakan konsisten pabila $\mathrm{CR} \leq 5 \%$, pada $\mathrm{f}=4$ dikatakan kosisten apabila $\mathrm{CR} \leq$ $8 \%$ dan pada $\mathrm{f} \geq 3$ dikatakan konsisten apabila $\mathrm{CR} \leq 10 \%[15]$

$$
C R=\frac{C I}{R I}
$$

Di mana:

RI : Random Consistency Index

Nilai RI bisa didapatkan dengan melihat Tabel 2.

Tabel 2. Tabel Random Consistency Index

\begin{tabular}{|ccccccccccc|}
\hline $\mathbf{f}$ & $\mathbf{1}$ & $\mathbf{2}$ & $\mathbf{3}$ & $\mathbf{4}$ & $\mathbf{5}$ & $\mathbf{6}$ & $\mathbf{7}$ & $\mathbf{8}$ & $\mathbf{9}$ & $\mathbf{1 0}$ \\
\cline { 2 - 12 } RI & 0 & 0 & 0.52 & 0.89 & 1.11 & 1.25 & 1.35 & 1.4 & 1.45 & 1.49 \\
\hline
\end{tabular}

\section{HASIL DAN PEMBAHASAN}

\subsection{Rata-rata Geometrik}

Hasil perhitungan rata-rata geometrik untuk masing-masing kriteria adalah sebagai berikut:

Tabel 3. Tabel Rata-rata Geometrik untuk masing-masing kriteria

\begin{tabular}{|lcccccc|}
\hline \multirow{2}{*}{\multicolumn{1}{c}{ Kriteria }} & \multicolumn{4}{c}{ Skor } & Rata-rata \\
\cline { 2 - 5 } & 1 & 2 & 3 & 4 & Geometrik \\
\hline Fleksibilitas Waktu Kuliah & 28 & 32 & 8 & 8 & 1.739 \\
Kemudahan Memahami Materi & 9 & 7 & 24 & 36 & 2.908 \\
Kemudahan Pengumpulan Tugas & 35 & 25 & 7 & 9 & 1.638 \\
Kemudahan Interaksi Dengan Pengajar & 4 & 12 & 37 & 23 & 2.897 \\
\hline
\end{tabular}

Berdasarkan Tabel, 3 dapat diketahui bahwa kemudahan memahami materi menjadi kriteria dengan nilai rata-rata geometrik terbesar disusul dengan kemudahan interaksi dengan pengajar. 
Tabel 4. Tabel Rata-rata Geometrik untuk masing-masing alternatif per kriteria

\begin{tabular}{|lccccccc|}
\hline \multicolumn{1}{c}{ Kriteria } & \multicolumn{9}{c}{ Skor } & & Rata-rata \\
\cline { 2 - 5 } & $\mathbf{1}$ & $\mathbf{2}$ & $\mathbf{3}$ & $\mathbf{4}$ & $\mathbf{5}$ & Geometrik \\
\hline Fleksibilitas Waktu Kuliah & & & & & & \\
Tatap Muka & 0 & 0 & 11 & 31 & 23 & 4.123 \\
E-learning & 0 & 0 & 1 & 5 & 5 & 4.313 \\
Kemudahan Memahami Materi & & & & & & \\
Tatap Muka & 0 & 0 & 2 & 26 & 37 & 4.502 \\
E-learning & 0 & 0 & 6 & 4 & 1 & 3.489 \\
Kemudahan Pengumpulan Tugas & & & & & & \\
Tatap Muka & 1 & 9 & 5 & 32 & 18 & 3.701 \\
E-learning & 0 & 0 & 0 & 7 & 4 & 4.338 \\
Kemudahan Interaksi Dengan Pengajar & & & & & & \\
Tatap Muka & 0 & 0 & 2 & 25 & 38 & 4.517 \\
E-learning & 0 & 0 & 7 & 4 & 0 & 3.331 \\
\hline
\end{tabular}

Berdasarkan Tabel 4, dapat dilihat bahwa pada kriteria fleksibilitas waktu kuliah dan kemudahan pengumpulan tugas, alternatif e-learning memiliki rata-rata geometrik yang lebih besar daripada tatap muka. Sedangkan sebaliknya pada kriteria kemudahan memahami materi dan kemudahan interaksi dengan pengajar, alternatif tatap muka memiliki rata-rata geometrik yang lebih besar daripada e-learning.

\subsection{Selisih Terbesar}

Setelah rata-rata geometrik didapatkan, dilanjutkan dengan menghitung selisih rata-rata geometrik terbesar. Hasil selisih rata-rata geometrik terbesar dapat dilihat pada Tabel 5.

Tabel 5. Tabel Selisih Terbesar

\begin{tabular}{|lccc|}
\hline \multicolumn{1}{|c}{ Kriteria } & $\begin{array}{c}\text { Nilai } \\
\text { Tertinggi }\end{array}$ & $\begin{array}{c}\text { Nilai } \\
\text { Terendah }\end{array}$ & Selisih \\
\hline Antar Kriteria & 2.908 & 1.638 & 1.270 \\
Fleksibilitas Waktu Kuliah & 4.313 & 4.123 & 0.190 \\
Kemudahan Memahami Materi & 4.502 & 3.489 & 1.013 \\
Kemudahan Pengumpulan Tugas & 4.338 & 3.701 & 0.637 \\
Kemudahan Interaksi Dengan Pengajar & 4.517 & 3.331 & 1.186 \\
\hline
\end{tabular}

Berdasarkan Tabel 5, selisih terbesar antar kriteria adalah sebesar 1.27. Sedangkan selisih terbesar antar alternatif pada kriteria fleksibilitas waktu kuliah, kemudahan memahami materi, kemudahan pengumpulan tugas dan kemudahan interaksi dengan pengajar secara berturut-turut sebesar 0.19, 1.013, 0.637 dan 1.186. Nilai selisih rata-rata geometrik pada masing-masing kriteria ini selanjutnya digunakan untuk menghitung matriks banding berpasangan.

\subsection{Matriks Banding Berpasangan}

Tahap selanjutnya adalah menghitung matriks banding berpasangan. Hasil matriks banding berpasangan terdapat pada Tabel 6, sebagai berikut: 
Tabel 6. Matriks Banding Berpasangan Antar Kriteria

\begin{tabular}{|ccccc|}
\hline Matriks Banding Berpasangan & $\begin{array}{c}\text { Fleksibilitas } \\
\text { Waktu } \\
\text { Kuliah }\end{array}$ & $\begin{array}{c}\text { Kemudahan } \\
\text { Memahami } \\
\text { Materi }\end{array}$ & $\begin{array}{c}\text { Kemudahan } \\
\text { Pengumpulan } \\
\text { Tugas }\end{array}$ & $\begin{array}{c}\text { Kemudahan } \\
\text { Interaksi } \\
\text { Dengan } \\
\text { Pengajar }\end{array}$ \\
\hline Fleksibilitas Waktu Kuliah & 1.000 & 0.120 & 1.639 & 0.121 \\
Kemudahan Memahami Materi & 8.361 & 1.000 & 9.000 & 1.066 \\
Kemudahan Pengumpulan Tugas & 0.610 & 0.111 & 1.000 & 0.112 \\
Kemudahan Interaksi Dengan Pengajar & 8.296 & 0.938 & 8.934 & 1.000 \\
\hline
\end{tabular}

Berdasarkan Tabel 6, diperoleh hasil sebagai berikut, pertama kemudahan memahami materi memiliki bobot 8.361 kali lebih besar dibandingkan flesibilitas waktu kuliah. Kedua fleksibilitas waktu kuliah memiliki bobot 1.639 kali lebih besar dibandingkan kemudahan pengumpulan tugas. Ketiga kemudahan interaksi dengan pengajar memiliki bobot 8.296 kali lebih besar dibandingkan fleksibilitas waktu kuliah. Keempat kemudahan memahami materi memiliki bobot 9 kali lebih besar dibandingkan kemudahan pengumpulan tugas. Kelima kemudahan memahami materi memiliki bobot 1.066 kali lebih besar dibandingkan kemudahan interaksi dengan pengajar. Keempat kemudahan interaksi dengan pengajar memiliki bobot 8.934 kali lebih besar dibandingkan kemudahan pengumpulan tugas.

Matriks banding pasangan antar alternatif pada masing- masing kriteria disajikan pada Tabel 7- 10 sebagai berikut:

Tabel 7. Matriks Banding Berpasangan Antar Alternatif pada Kriteria Fleksibilitas Waktu Kuliah

\begin{tabular}{|ccc|}
\hline Matriks Banding Berpasangan & Tatap Muka & E-learning \\
\hline Tatap Muka & 1.000 & 0.111 \\
E-learning & 9.000 & 1.000 \\
\hline
\end{tabular}

Berdasarkan Tabel 7 diperoleh hasil pada kriteria fleksibilitas waktu kuliah, e-learning memiliki bobot 9 kali lebih besar dibandingkan tatap muka.

Tabel 8. Matriks Banding Berpasangan Antar Alternatif pada Kriteria Kemudahan Memahami Materi

\begin{tabular}{|ccc|}
\hline Matriks Banding Berpasangan & Tatap Muka & E-learning \\
\hline Tatap Muka & 1.000 & 9.000 \\
E-learning & 0.111 & 1.000 \\
\hline
\end{tabular}

Berdasarkan Tabel 8, diperoleh hasil pada kriteria kemudahan memahami materi, tatap muka memiliki bobot 9 kali lebih besar dibandingkan e-learning .

Tabel 9. Matriks Banding Berpasangan Antar Alternatif pada Kriteria Kemudahan Pengumpulan Tugas

\begin{tabular}{|ccc|}
\hline Matriks Banding Berpasangan & Tatap Muka & E-learning \\
\hline Tatap Muka & 1.000 & 0.111 \\
E-learning & 9.000 & 1.000 \\
\hline
\end{tabular}

Berdasarkan Tabel 9, diperoleh hasil pada kriteria kemudahan pengumpulan tugas, e-learning memiliki bobot 9 kali lebih besar dibandingkan tatap muka. 
Tabel 10. Matriks Banding Berpasangan Antar Alternatif pada Kriteria Kemudahan Interaksi Dengan Pengajar

\begin{tabular}{|ccc|}
\hline Matriks Banding Berpasangan & Tatap Muka & E-learning \\
\hline Tatap Muka & 1.000 & 9.000 \\
E-learning & 0.111 & 1.000 \\
\hline
\end{tabular}

Berdasarkan Tabel 10, diperoleh hasil pada kriteria kemudahan interaksi dengan pengajar, tatap muka memiliki bobot 9 kali lebih besar dibandingkan e-learning.

\subsection{Vektor Eigen}

Bobot pada masing-masing kriteria dapat dicari dengan cara menghitung rata-rata setiap baris yang ada di matriks normalitas seperti pada Persamaan 19. Hasil bobot dalam bentuk vektor eigen adalah sebagai berikut:

Tabel 11. Vektor Eigen Antar Kriteria

\begin{tabular}{|lc|}
\hline \multicolumn{1}{|c|}{ Kriteria } & Vektor Eigen \\
\hline Fleksibilitas Waktu Kuliah & 0.060 \\
Kemudahan Memahami Materi & 0.455 \\
Kemudahan Pengumpulan Tugas & 0.045 \\
Kemudahan Interaksi Dengan Pengajar & 0.439 \\
\hline
\end{tabular}

Berdasarkan Tabel 11, diperoleh hasil bahwa fleksibilitas waktu kuliah memiliki kontribusi $6 \%$ pada keseluruhan kriteria, kemudahan memahami materi memiliki kontribusi $45.5 \%$ pada keseluruhan kriteria, kemudahan pengumpulan tugas memiliki kontribusi $4.5 \%$ pada keseluruhan kriteria dan kemudahan interaksi dengan pengajar memiliki kontribusi $43.9 \%$ pada keseluruhan kriteria. Berdasarkan hasil tersebut juga dapat diperoleh informasi bahwa kemudahan memahami materi merupakan faktor utama dalam pemilihan metode pembelajaran yaitu sebesar $45.5 \%$, kemudian disusul oleh faktor kemudahan interaksi dengan pengajar dimana yaitu sebesar $43.9 \%$, sementara fleksibilitas waktu kuliah dan kemudahan pengumpulan tugas memiliki kontribusi sebesar $6 \%$ dan $4.5 \%$.

Tabel 12. Vektor Eigen Antar Kriteria

\begin{tabular}{|l|cc|}
\hline \multicolumn{1}{|c|}{ Kriteria } & \multicolumn{2}{|c|}{ Nilai } \\
\hline Kriteria Flaksibilitas Waktu Kuliah & Tatap Muka & 0.100 \\
Kriteria Kemudahan Memahami Materi & E-Learning & 0.900 \\
& Tatap Muka & 0.900 \\
Kriteria Kemudahan Pengumpulan Tugas & E-Learning & 0.100 \\
& Tatap Muka & 0.100 \\
Kriteria Kemudahan Interaksi Dengan Pengajar & E-Learning & 0.900 \\
& Tatap Muka & 0.900 \\
& E-Learning & 0.100 \\
\hline
\end{tabular}

Berdasarkan Tabel 12 diperoleh hasil sebagai berikut, pertama pada kriteria fleksibitilas waktu kuliah besar prioritas e-learning adalah sebesar 90\% sedangkan besar prioritas tatap muka adalah sebesar $10 \%$. Kedua pada kriteria kemudahan memahami materi besar prioritas e-learning adalah sebesar $10 \%$ sedangkan besar prioritas tatap muka adalah sebesar $90 \%$. Ketiga pada kriteria kemudahan pengumpulan tugas besar prioritas e-learning adalah sebesar $90 \%$ sedangkan besar prioritas tatap muka adalah sebesar $10 \%$. Keempat pada kriteria kemudahan pengumpulan tugas besar prioritas e-learning adalah sebesar $90 \%$ sedangkan besar prioritas tatap muka adalah sebesar $10 \%$.

Persentase hierarki pada masing-masing kriteria disajikan pada Gambar 3, sebagai berikut: 


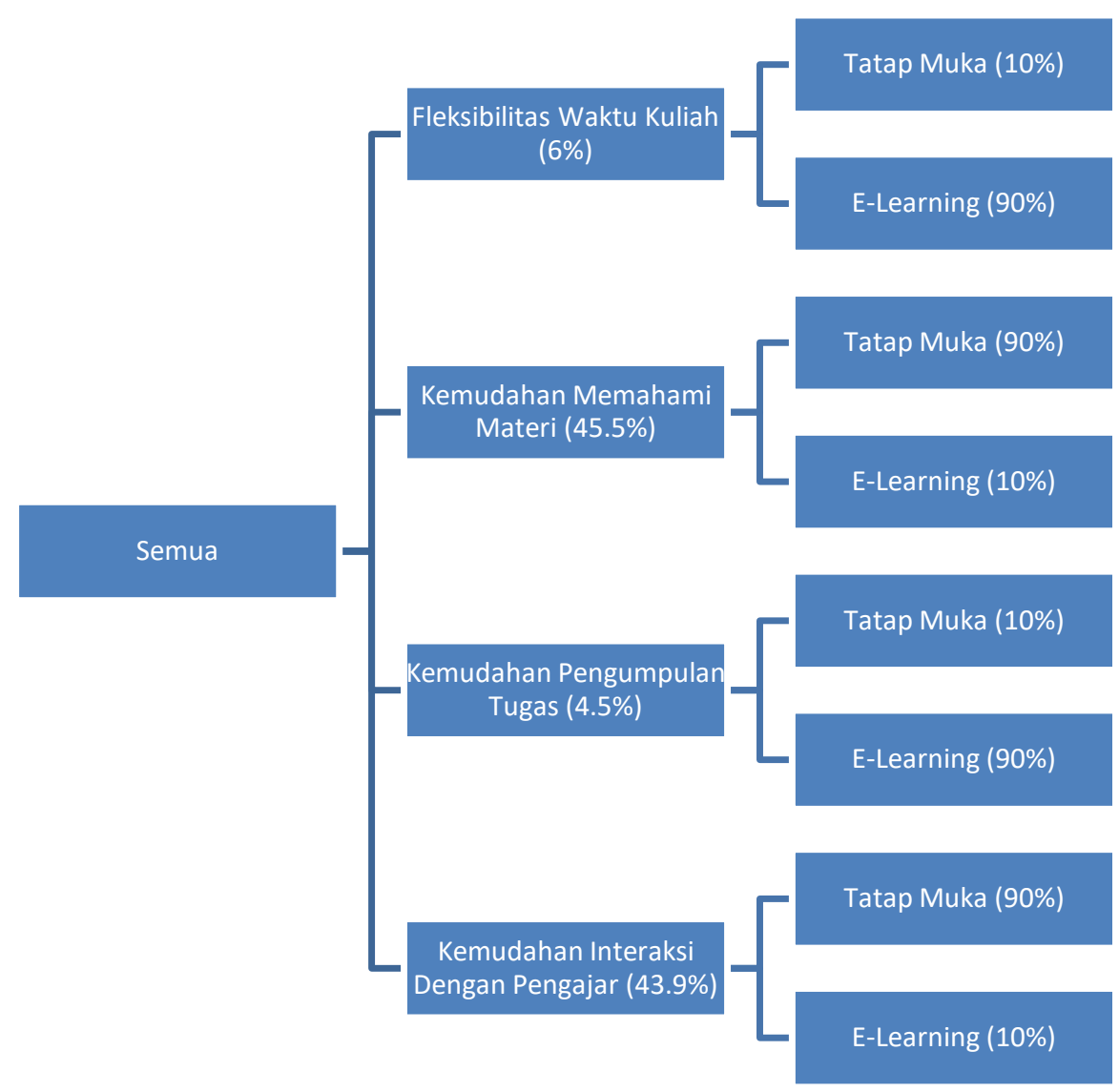

Gambar 3. Hierarki dengan bobot

Menurut responden berdasarkan kriteria fleksibilitas waktu kuliah, metode e-learning memiliki fleksibilitas waktu kuliah yang lebih baik daripada metode tatap muka. Hal tersebut juga terjadi pada kemudahan pengumpulan tugas, menurut responden metode $e$-learning lebih memudahkan pengumpulan tugas daripada metode tatap muka. Sementara itu metode tatap muka punya kelebihan dibandingkan $e$ learning yaitu ditinjau dari kemudahan interaksi dengan pengajar dan kemudahan memahami materi.

Tabel 13. Prioritas Menyeluruh

\begin{tabular}{|cc|}
\hline Metode & Prioritas Menyeluruh \\
\hline Tatap Muka & 0.815 \\
E-learning & 0.185 \\
\hline
\end{tabular}

Jika vektor eigen dari masing-masing alternatif dikalikan dengan vektor eigen kriteria maka didapatkan prioritas menyeluruh. Hasil prioritas menyeluruh dapat dilihat pada Tabel 13. Berdasarkan Tabel 13 dapat dilihat bahwa saat ini mahasiswa lebih cenderung memilih metode tatap muka dengan prioritas sebesar $81.5 \%$ jika dibandingkan e-learning yang hanya sebesar $18.5 \%$ dengan mempertimbangkan fleksibilitas waktu kuliah sebesar $6 \%$, kemudahan memahami materi sebesar $45.5 \%$, kemudahan pengumpulan tugas sebesar 4.5\% dan kemudahan interaksi dengan pengajar sebesar $43.9 \%$. Hasil penelitian ini sejalan dengan Rolisca dan Achadiyah [6], dimana dengan e-learning memiliki kelebihan yaitu waktu kuliah menjadi lebih fleksibel atau bisa dilakukan sewaktu-waktu. Namun e-learning juga punya kekurangan dari segi memahami materi yang dianggap masih sulit, serta sulitnya interaksi dengan pengajar.

\subsection{Mengukur Konsistensi}

Konsistensi matriks banding berpasangan pada analisis AHP perlu diukur dengan cara menghitung nilai Lamda Maksimal, CI dan setelah itu CR. Hasil perhitungan Lamda Maksimal, CI dan setelah itu CR adalah sebagai berikut: 
Tabel 14. Nilai Lamda Maks, CI dan CR

\begin{tabular}{|l|cc|}
\hline \multicolumn{1}{|c|}{ Kriteria } & \multicolumn{2}{c|}{ Nilai } \\
\hline \multirow{2}{*}{ Antar Kriteria } & Lamda Max & 4.023 \\
& CI & 0.008 \\
Kriteria Flaksibilitas Waktu Kuliah & CR & 0.008 \\
& Lamda Max & 2.000 \\
Kriteria Kemudahan Memahami Materi & CI & 0.000 \\
& CR & 0.000 \\
Kriteria Kemudahan Pengumpulan Tugas & Lamda Max & 2.000 \\
& CI & 0.000 \\
Kriteria Kemudahan Interaksi Dengan Pengajar & CR & 0.000 \\
& Lamda Max & 2.000 \\
& CI & 0.000 \\
& CR & 0.000 \\
& CI Max & 2.000 \\
& CR & 0.000 \\
\end{tabular}

Berdasarkan Tabel 14 dapat diketahui bahwa nilai Lamda Maksimal pada semua kriteria tidak lebih dari 5, sedangkan nilai CI serta CR pada semua kriteria sangat kecil yaitu kurang dari 1\% sehingga dapat dikatakan bahwa semua matriks banding berpasangan sehingga hasil AHP dapat digunakan dalam pengambilan keputusan.

\section{KESIMPULAN}

Berdasarkan hasil penelitian, dapat disimpulkan bahwa mahasiswa lebih memilih metode tatap muka jika dibandingkan e-learning karena dengan tatap muka lebih mudah memahami materi dan lebih mudah berinteraksi dengan pengajar. Namun e-learning juga memiki keunggulan yaitu memudahkan pengumpulan tugas dan waktu yang fleksibel. Berdasarkan pendapat mahasiswa, alangkah lebih baik jika metode tatap muka dikombinasi dengan metode e-learning di mana penyampaian materi tetap menggunakan tatap muka dan pengumpulan tugas menggunakan e-learning sehingga pembelajaran bisa menjadi optimal.

\section{UCAPAN TERIMA KASIH}

Terima kasih kepada Universitas Muhammadiyah Sidoarjo yang telah mendanai riset ini melalui riset internal. Tak lupa kami ucapkan terima kasih juga kepada Angga Dwi Mulyanto, M.Si., Dosen di Universitas Islam Negeri Maulana Malik Ibrahim Malang yang telah bersedia berdiskusi banyak mengenai Analytical Hierarchy Process (AHP).

\section{DAFTAR PUSTAKA}

[1] Y. Yamasari, "Fasilitas Evaluasi yang Menggabungkan Pengukuran, Bimbingan dan Penilaian dalam Sistem e-learning," Jurnal Penelitian Pendidikan Matematika Dan Sains, vol. 15, no. 1, 2008.

[2] S. P. Suparto, "Evaluasi Program E-learning Bagi Petugas Lapangan," Cakrawala Pendidikan, vol. 12, no. 1, pp. 112-128, 2012.

[3] A. Sutedjo, "Implementasi dan Evaluasi Pembelajaran E-learning Pada Mata Kuliah Geografi Transportasi dan Komunikasi Mahasiswa yang Memprogram di Semester Gasal Tahun Akademik 2012/2013, ” Jurnal Geografi, vol. 11, no. 21, pp. 51-63, 2013.

[4] N. S. Hanum, "Keefektifan E-learning Sebagai Media Pembelajaran (Studi Evaluasi Model Pembelajaran Elearning SMK Telkom Sandhy Putra Purwokerto)," Jurnal Pendidikan Vokasi, vol. 3, no. 1, pp. 90-102, 2013.

[5] T. R. Usaheni dan E. Fahmi, "Evaluasi Tingkat Kematangan E-learning Berdasarkan E-learning Maturity Model (eMM) Di Universitas Riau," Jurnal Pendidikan Teknologi Dan Kejuruan, vol. 2, no. 1, 2013.

[6] R. U. C. Rolisca dan B. N. Achadiyah, "Pengembagnan Media Evaluasai Pembelajaran dalam Bentuk Online Berbasis E-learning Menggunakan Software Wondershare Quiz Creator Dalam Mata Pelajaran Akuntansi 
SMA Brawijaya Smart School (BSS),” Jurnal Pendidikan Akuntansi Indonesia, vol. 12, no. 1, pp. 41-48, 2014.

[7] Felix, "Evaluasi Penerapan E-learning Di Jurusan Akuntansi Fakultas Bisnis dan Ekonomika Universitas Surabaya," Calyptra: Jurnal Ilmiah Mahasiswa Universitas Surabaya, vol. 3, no. 1, pp. 1-14, 2014.

[8] R.E.I. Ahadiah, "Pengembangan Media Pembelajaran berbasis E-learning Pada Mata Pelajaran Teknik Listrik Di SMK Negeri 3 Surabaya", vol 05 No. 3, pp.1005-1012, 2016.

[9] D. G. H. Divayana, “Evaluasi Pemanfaatan E-learning Menggunakan Model CSE-UCLA,” Cakrawala Pendidikan, vol. 34, no. 2, pp. 280-289, 2017.

[10] L. Martino, D. Luengo and J. Miguez, Independent Random Sampling Methods, Springer, 2018.

[11] Expert Choice, "Expert Choice," Expert Choice, 2018. [Online]. Tersedia: https://www.expertchoice.com/. [Diakses 2018 October 17].

[12] H. Ekawati, Penentuan Prioritas Mahasiswa Dalam Memilih SImcard Prabayar GSM Menggunakan Analytical Hierarchy Process (AHP) (Studi Kasus di Universitas Brawijaya), Malang: Universitas Brawijaya, 2006.

[13] L. Rensis, A Technique for the Measurement of Attitudes, New York: New York University, 1932.

[14] L. G.Bruce, E.A. Wasil, J.M. Alexander and P.T Harker, The Analytic Hierarchy Process: Applications and Studies, Springer Science \& Business Media, 2012.

[15] T. L. Saaty, Fundamentals of Decision Making and Priority Theory with the Analytic Hierarchy Process, Pittburg: RWS Publications, 1994. 